Case report

\title{
FIRST REPORT ON Centrorhynchus aluconis IN COMMON BUZZARD (Buteo buteo) IN NORTHWEST IRAN
}

\author{
SHIRAZI Shahrokh ${ }^{1 *}$, HESARAKI Saeed ${ }^{1}$, MOSTAFAEI Tayebe-Sadat $^{1}$, DAVOODI \\ Jaber $^{2}$
}

${ }^{1}$ Department of Veterinary Pathobiology, Science and Research Branch, Islamic Azad University, Tehran, Iran; ${ }^{2}$ Department of Veterinary Parasitology, Islamic Azad University of Abhar Branch, Abhar, Iran

(Received 23 January; Accepted 10 February 2014)

In July 2012 a male Common Buzzard (Bute obuteo) from the Department of Environment of East Azerbaijan was sent to the Parasitology Laboratory at the School of Specialized Sciences of Veterinary Medicine, Science and Research Unit, Tehran Islamic Azad University. Gastrointestinal parasites were isolated and sent to the Iranian National Parasitology Museum in order to specify the diagnosis. It was determined that the bird was infected with the acanthocephalan Centrorbynchu saluconis. This is the first report of Common Buzzard infestation with this parasite in Iran.

Key words: Centrorbynchusaluconis, Common Buzzard, Histopathology

\section{INTRODUCTION}

The most common definitive host for Centrorbynchusaluconis belongs to orders Falconiformes and Strigiformes [1,2]. This case presentation describes the first report of Centrorbynchusaluconis in a Common Buzzard (Buteo buteo) in Iran.

\section{CASE PRESENTATION}

Common Buzzard (Buteo buteo) is a raptor bird smaller than an eagle (medium size is $50-55 \mathrm{~cm}$ ), with a small head, wide wings and a short tail. Common Buzzard is a protected animal species which belongs to the order Falconiformes, family Accipitridae (Fig. 1).

According to the protection rules given by the Department of Environment in Iran, collecting a suitable amount of samples is difficult, which implies limited information about their health. There are only a few reports of wild bird infection, especially Common Buzzard, with acanthocephalans all over the world and this is the first report of Common Buzzard infestation with Centrorbynchus aluconis in Iran.

* Corresponding author: e-mail: sh.shirazi@srbiau.ac.ir 
In July 2012 a male Common Buzzard was found by the environment watchers in Kaleybar (38 $86 \mathrm{~N}^{\prime}$ and $47^{\circ} 04^{\prime} \mathrm{E}$ north east of East Azerbaijan). The bird's wings were broken and severe bleeding was present. The bird died despite of the given medical care. The bird was not treated with antiparasitic drugs prior to the incident, nor was kept in captivity.

After necropsy and tissue sampling, the digestive tract was sent to the Laboratory of parasitology, at the School of Specialized Sciences of Veterinary Medicine, Science and Research Unit, Tehran Islamic Azad University. The parasites were isolated by washing the intestines and passing the contents through a sieve. For histopathology, the tissue specimens were fixed in 10\% formalin, and after routine tissue processing the parasite was identified based on its morphological features. Morphological changes in the small intestine were described, as well.

Out of the 9 acanthocephalans, 3 of them were found in the intestinal contents freely and the others penetrated with their oral proboscis into the small intestine wall. For further examination, all the specimens were sent to the Iranian National Parasitology Museum. The morphology of the oral proboscis, size, and the number of rows and spines were measured and counted. Morphological characteristic of free acanthocephalans [3], and also histological features from attached acanthocephalans in the intestine, as well as the results obtained from the Parasitology Museum have confirmed that all of the specimens were Centrorbynchusaluconis.

Chronic granulomatous enteritis was the most prominent histological finding. Attached adult parasites within the small intestine wall and encapsulated larval stages were present [4]. The inflammatory tissue reaction was intensive around the attachment of the adult worms. Granulomas surrounded by fibrous tissue were composed of a large number of macrophages and foreign body giant cells around the necrotic areas in the Lamina propria mucosae. Furthermore, fused short villi and cryptitis were present, as well (Fig 2).
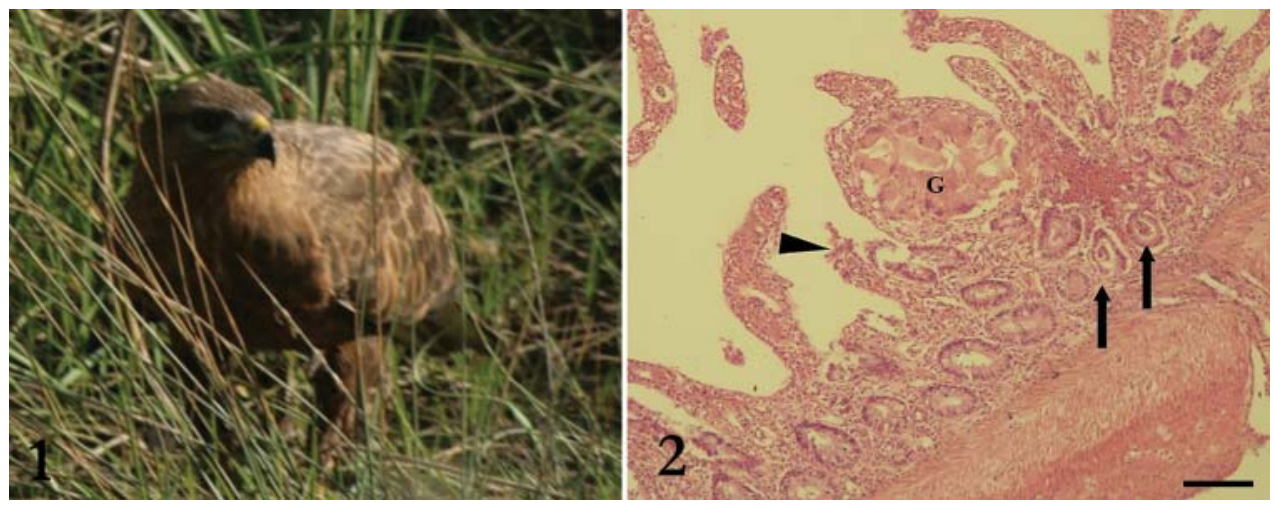

Figure 1. Common Buzzard (Buteo buteo); Figure 2. Sections of small intestine with fused short villi (arrow head) and cryptitis (arrow). A granuloma with many giant cells (G) is shown in the lamina propria. HE, Barr: $200 \mu \mathrm{m}$ 


\section{DISCUSSION}

There are a few parasitological studies on Centrorbynchusaluconis especially in wild birds. Common Buzzard infestation with acanthocephalans has not been reported in Iran while there are surveys about this parasitic infection in raptor birds in other countries [5]. El-Dakhly et al, 2012 on necropsy and analysis of intestinal contents of a dead Japanese golden eagle described this acanthocephalan among other intestinal parasites and according to the lesions it was suspected that intestinal parasites were the cause of eagle death [6]. American researchers in 1998 reported infection by Centrorbynchus $S p$ in $10 \%$ of 19 eagles in Florida, USA [7,8]. Infestations with the other species of acanthocephalans have been reported by other researchers [8]. Richardson and Cole, 1997 in a survey of eagles in North America reported some species of acanthocephalans, but there was no report of Centrorbynchus Sp. Bolette in 2007 described Oligacanthorbynchusnickolin in owls and a hawk from central Arizona, USA $[9,10]$. With the study on falconiformes and strigiformes in Mexico various gastrointestinal parasites were described by Santos et al, 2011 but none of them were acanthocephalans [11]. There is no report of this acanthocephalan in Nestling Redshouldered hawks (Buteo lineatus) in northeast Wisconsin [12]. According to prevoius studies it has been shown that this acanthocephalan is not a common parasite in Common Buzzard but owls are one of the most important hosts for it.

Centrorbynchusaluconis is the most common helminth in Tawny Owls in Great Britain. It is suggested that this specie is dependent on shrews (Sorexaraneus and Sorexminutus) as a paratenic host [13]. In 2004 this parasite with the highest prevalence was described in six species of owls in Spain [14]. This acanthocephalan has been reported also in mammals. The study carried out in the United Kingdom found that encysted acanthocephalans, which belong to the Centrorbynchus Sp. were found in the body cavities of common shrew and pygmy shrew. It seems that shrews are paratenic hosts for $C$. aluconis [15]. The larval stage of $C$. aluconis was described from shrews in Russia [16]. There is a report of infection of $4.6 \%$ stray domestic cats in Dubai with this acanthocephalan [17]. Investigations on protected bird species are of interest for other authors [18].

Finally it is suggested that there is not a clear rate of $C$. aluconis prevalence in wild birds of Iran and it is the first report of infestation with this parasite in northwest Iran. Further investigation will highlight this subject.

\section{Acknowledgement}

We thank department of environment of East Azerbaijan especially Dr. BiukReisiand

Dr. Hosseini Qomiand thank Expert of Iranian National Parasitology Museum, Prof. Iraj Mobedi. 


\section{REFERENCE}

1. Golvan, YJ: Nomenclature of the Acanthocephala. Research and Reviews in Parasitology, 1994, 54, 135-205.

2. Dimitrova ZM, Gibson DI: Some species of Centrorhynchus Lühe, 1911 (Acanthocephala: Centrorhynchidae) from the collection of the Natural History Museum, London. Syst Parasitol 2005, 62 (2): 117-34.

3. Yamaguti S: Systema Helminthum. Vol. 5. Interscince Publishers, New York, USA: A Division of John Wiley \& Sons, 1963.

4. La Salaa LF, Pereza AM, Smitsa JE, Martorellia SR: Pathology of enteric infections induced by the acanthocephalan Profilicollischasmagnathi in Olrog's gull, Larusatlanticus, from Argentina. J Helminthol 2013, 87 (1): 17-23.

5. Ishak DH, Loiseau C, Hull AC, Sehgal RNM: Prevalence of blood parasites in migrating and wintering California Hawks. J Raptor Res 2010, 44 (3): 215-223.

6. El-Dakhly K, El-Nahass el-S, Sudo A, Uchida T, Kakogawa M, Hirata A, Sakai H, Yanai T: Helminth fauna of a Japanese golden eagle, Aquila chrysaetos japonica. J Zoo Wildl Med 2012, 43 (4): 966-70.

7. Kinsella JM, Foster GW, Cole RA and Forrester DJ: Helminth Parasites of the bald eagle, Haliaeetusleucocephalus, in Florida. J Helminthol Soc Wash 1998, 65 (1): 65-8.

8. Tuggle BN, Schmeling SK: Parasites of the bald eagle (Haliaeetus Leucocephalus) of North America. J Wildl Dis 1982, 18(4): 501-6.

9. Bolette DP: A new oligacanthorhynchid acanthocephalan described from the great horned owl, Bubo virginianus (Strigidae), and red-tailed hawk, Buteo jamaicensis (Accipitridae), from central Arizona, USA. J Parasitol 2007, 93(1): 120-8.

10. Richardson DJ, Cole RA: Acanthocephala of the bald eagle (Haliaeetusleucocephalus) in North America. J Parasitol 1997, 83(3):540-1.

11. Santos T, de Oliveira JB, Vaughan C and Santiago H: Health of an ex situ population of raptors (Falconiformes and Strigiformes) in Mexico: diagnosis of internal parasites. Rev Biol Trop 2011, 59(3):1265-74.

12. King JC, Dubay SA, Huspeni TC, VanLanen AR, Gerhold RW: Parasite infections in nestling red-shouldered hawks (Buteo lineatus) in northeast Wisconsin. J Parasitol 2010, 96 (3): 535-40.

13. Ewald JA, Crompton DW:Centrorhynchusaluconis (Acanthocephala) and other helminth species in tawny owls (Strixaluco) in Great Britain. J Parasitol 1993, 79 (6): 952-4.

14. Ferrer D, Molina R, Castellà J, Kinsella JM: Parasitic helminths in the digestive tract of six species of owls (Strigiformes) in Spain. Vet J 2004, 167 (2): 181-5.

15. Ewald JA, Crompton DW, Johnson I, Stoddart RC: The occurrence of Centrorhynchus (Acanthocephala) in shrews (Sorexaraneus and Sorexminutus) in the United Kingdom. J Parasitol 1991, 77 (3): 485-7.

16. Kirillova N,Kirillov AA: First finding of the Centrorhynchusaluconis (Muller, 1780) (Giganthorhynchidae) and Moniliformis moniliformis Bremser, 1811 (Moniliformidae) larvae in shrews (Insectivora: Soricidae) of the fauna of Russia. Parazitologiia 2007, 41(1):82-5.

17. Schuster RK, Thomas K, Sivakumar S, O'Donovan D: The parasite fauna of stray domestic cats (Feliscatus) in Dubai, United Arab Emirates. Parasitol Res 2009, 105 (1): 125-34. 
18. Stevanov-Pavlović M, Vučićević M, Bošnjak J, Stevanović J, Dimitrijević V, Resanović R, Stanimirović Z: Molecular sex determination of 20 bird species protected in the Republic of Serbia, Acta Vet (Beograd) 2013, 63(1):45-51.

\title{
PRVI SLUČAJ Centrorhynchus aluconis-a KOD ORLA MIŠARA (Buteo buteo) U SEVEROZAPADNOM IRANU
}

\author{
SHIRAZI Shahrokh, HESARAKI Saeed, MOSTAFAEI Tayebe-Sadat, \\ DAVOODI Jaber
}

Tokom jula 2012. mužjak orla mišara (Buteo buteo) je poslat iz Departmana za životnu sredinu istočnog Azarbejdžana u Laboratoriju za parazitologiju Škole za specijalizovane nauke veterinarske medicine, Odeljenje za nauku i istraživanja, Teheranski islamski Azad univerzitet. Izolovani gastrointestinalni paraziti su poslati radi specifikacije i dijagnostike u Nacionalni parazitološki muzej. Utvrđeno je da je ptica zaražena sa Centrorbynchus aluconis. U prikazu prvog slučaja dat je opis infestacije orla mišara parazitom Centrorbynchus aluconis, na području Irana. 